\title{
PENDUGAAN NILAI TAHANAN JENIS BATUAN UNTUK MENGETAHUI STRUKTUR GEOLOGI PADA ENDAPAN VULKANIK DI KEC. PADARINCANG, PROVINSI BANTEN.
}

\author{
Oleh: \\ Cipta Endyana, Febri Hirnawan, Hendarmawan, Undang Mardiana \\ Fakultas Teknik Geologi, Universitas Padjadjaran \\ Jalan Raya Bandung-Sumedang km 21, Jatinangor-Sumedang
}

\begin{abstract}
SARI
Pendugaan nilai-nilai tahanan jenis batuan menggunakan metode Schlumberger merupakan pendekatan yang efektif untuk menduga kondisi batuan bawah permukaan. Penggunaan teknik interpolasi dan pengelompokkan nilai tahanan jenis lebih lanjut dapat menafsirkan kontinuitas lateral jenis batuan dan struktur geologi.Pengolahan dan pengujian secara statistik analisis regresi berganda pada nilai tahanan jenis menghasilkan enam jenis kelompok batuan, yaitu: Breksi grain supported, Tuf Lapili, Tuf Kasar, Breksi grain supported, tuf lapili, breksi matrix supported. Hasil uji korelasi pada karakter tahanan jenis keenam kelompok batuan tersebut ditemukan bahwa ada tiga sumber material yang berbeda pada saat pengendapannya. Material endapan diyakini berasal dari Gunung Parakasak, Gunung Karang dan Gunung Kamuning. Kesamaan nilai tahanan jenis pada pola berarah barat-timur menunjukkan kesamaan litologi, sedangkan kesamaan nilai tahanan jenis pada pola dengan arah utara-selatan menunjukkan nilai kontras tahanan jenis yang disebabkan oleh dua jenis sesar berarah relatif barat-timur dengan mekanisme yang berbeda.
\end{abstract}

Kata Kunci : Tahanan jenis, struktur geologi, Padarincang, model bawah permukaan.

\section{ABSTRACT}

Geoelectric sounding using Schlumberger method is an effective approach to interpret the condition of subsurface. Advance processing with interpolation techniques and grouping of resistivity value can be used to interpret lateral continuity of rock types and geological structure. Statistical analysis with multiple regression and hierarchy cluster on resistivity values obtained six rock types, namely: grain-supported breccia, lapilli tuff, coarse tuff, grain-supported breccia, lapilli tuff, matrix-supported breccia. Correlation test based on the character of resistivy value revealed that there are three different sources of material deposit. Material deposit sources were believed to be originate from Mt. Parakasak, Mt. Karang and Mt. Kamuning. The similarity of resistivity values from the west to east shows the similarity of lithology, while in the north-south direction indicates the contrast value of resistivity caused by two faults trending relatively west to east direction with different mechanism.

Keyword : Resistivity, geological structure, Padarincang, subsurface modeling.

\section{PENDAHULUAN}

Fenomena air tanah yang melimpah terdapat di daerah vulkanik di Kecamatan Padarincang, Banten. Daerah ini terletak di antara Gunung Karang dan Gunung Parakasak yang merupakan lembah dari kedua gunung tersebut. Daerah penelitian secara administratif termasuk dalam Kecamatan Padarincang, Kabupaten Serang, Provinsi Banten. Secara geografis berada pada koordinat 606874-617578 meter timur dan 9305910-9317315 meter utara pada proyeksi UTM Zona 48 South dengan datum WGS 84. Sebelah utara dibatasi oleh adanya Rawa Danau, sebelah selatan dibatasi oleh adanya Gunung Parakasak dan Gunung Karang (Gambar 1).

Sudah sejak lama masyarakat memanfaatkan airtanah ini untuk kehidupannya sehari-hari, akan tetapi dalam pengelolaannya masih kurang baik akibat potensi airtanah yang tidak diketahui secara pasti, baik jumlah atau kapasitas cadangan maupun kualitas airtanahnya itu sendiri, bahkan bentuk dan geometri cekungannya. Keterdapatan airtanah tersebut berdasarkan teori terdapat pada batuan yang poros atau memiliki pori-pori, semakin besar nilai porositas batuannya akan semakin banyak kandungan airnya. Batuan yang poros ini dinamakan akifer airtanah. Biasanya batuan yang tergolong jenis akifer itu adalah breksi, pasir dan tuff kasar. Sedangkan batuan yang tidak poros dikatakan sebagai batuan impermeable berupa batuan yang keras seperti lava atau batuan yang berbutir sangat halus seperti lempung.

Daerah vulkanik terdiri atas batuan yang tersusun dari hasil erupsi gunung api. Kegiatan 


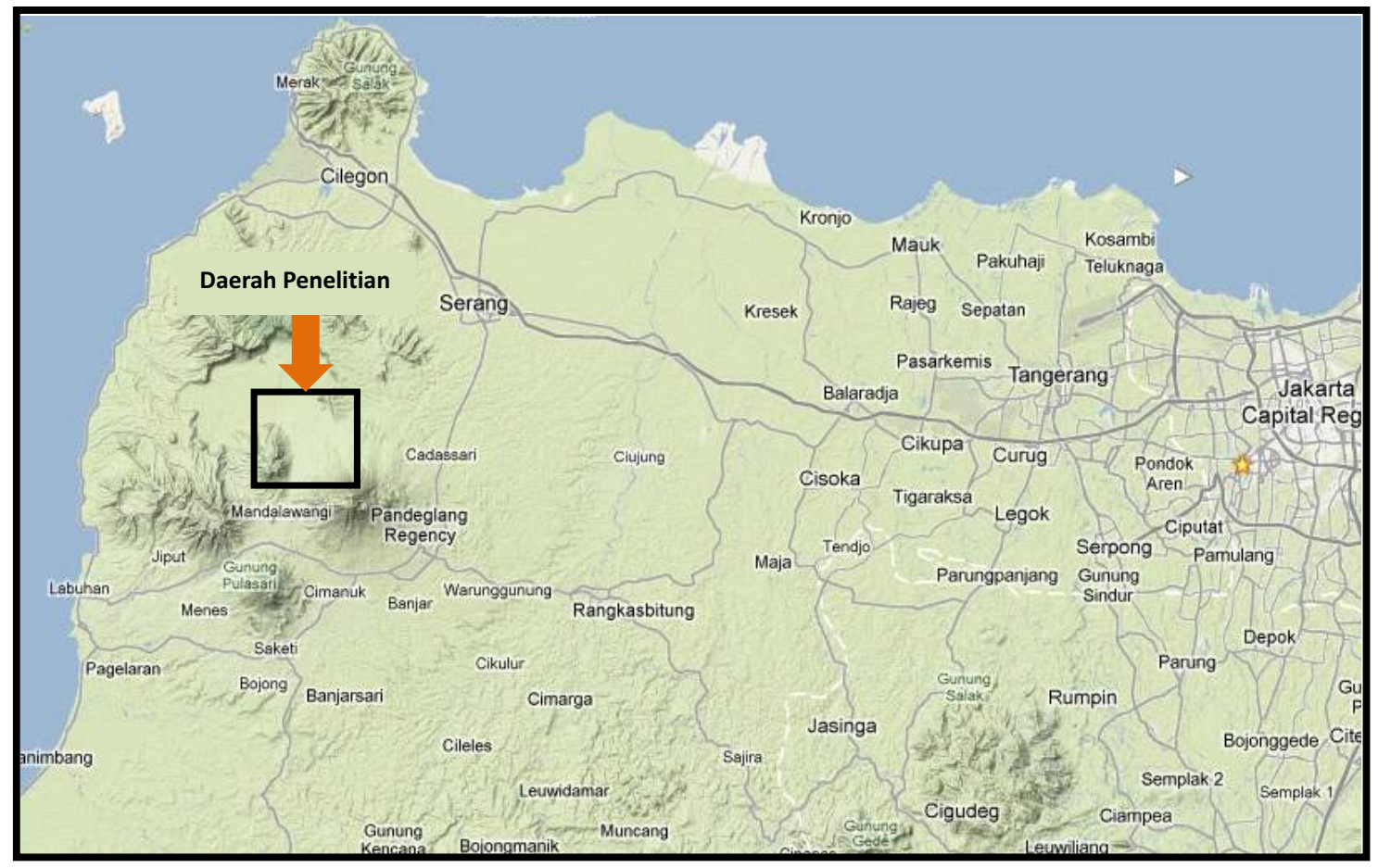

Gambar 1. Daerah Penelitian di Kec. Padarincang, Kab. Serang, Provinsi Banten.

vulkanisma memiliki karakter tersendiri dalam mengendapkan batuannya, diantaranya memiliki perubahan lateral pada jarak yang dekat dan batuannya sangat bervariasi serta tidak berlapis (Cas \& Wright, 1987; Nemeth \& Martin, 2007). Perbedaan batuan yang bervariasi dan tidak adanya perlapisan menjadi satu kendala dalam membuat interpretasi batuan penyusun di bawah permukaan.

Airtanah pada batuan terdapat dalam suatu akifer (lapisan yang dapat melalukan air) melalui pori-pori batuan atau disebut dengan porositas primer. Selain itu ada pula air yang mengisi ruang atau zona struktur geologi berupa kekar atau patahan yang disebut sebagai porositas sekunder. Porositas sekunder inilah yang harus diketahui keberadaannya disebabkan pengaruhnya yang sangat besar pada perhitungan cadangan airtanah di dalam suatu cekungan.

Model cekungan airtanah merupakan suatu pendekatan dalam rangka mengetahui susunan batuan vulkanik dan pola penyebaran serta geometrinya (Oosterbaan dkk., 1996). Model cekungan airtanah ini tidak hanya menjelaskan batuan penyusun suatu cekungan airtanah tetapi lebih jauh lagi harus dapat menjelaskan mengenai kemampuan batuan tersebut menyimpan airtanah serta struktur geologi yang berkembang. Pendekatan nilai tahanan tahanan jenis dengan menggunakan pendugaan geolistrik Metode Schlumberger merupakan suatu pendekatan yang cukup baik dalam menduga batuan penyusun di bawah permukaan dalam eksplorasi airtanah.

Selain itu, metode ini juga baik untuk mengetahui kemenerusan (lateral continuity) suatu nilai tahanan jenis batuan (identik dengan litologi) dalam membuat suatu model cekungan airtanah yang digunakan sebagai dasar interpolasi dan pembatasan nilai tahanan jenis batuan karena proses penafsiran cekungan airtanah (sebagai kasus probabilistik) memerlukan pengujian secara statistik (Hald, 1952; Hirnawan, 2007).

Pembuatan model cekungan airtanah ini juga akan sangat bermanfaat dalam kajian lain seperti misalnya eksplorasi mineral. Visualisasi yang terukur dari kondisi geologi bawah permukaan akan sangat membantu dalam interpretasi keberadaan struktur geologi sebagai salah satu fokus eksplorasi sumber daya geologi, khususnya di daerah vulkanik.

\section{METODOLOGI}

Penelitian ini didasarkan pada sebaran dan karakteristik nilai tahanan jenis yang diukur pada daerah penelitian dengan menggunakan metode Schlumberger 1D. Selanjutnya, nilai tahanan jenis tersebut diolah menggunakan perangkat lunak Progress.

Langkah selanjutnya adalah tahap analisis statistik untuk membuat kelompok nilai tahanan jenis berdasarkan karakter nilai tahanan jenis batuan yang tersebar dengan menggunakan 
Metode Hierarchy Cluster (Hald, 1952; Supranto, 2004). Pada kelompok-kelompok nilai tahanan jenis tersebut kemudian dilakukan kajian statistik yaitu dengan menggunakan analisis regresi berganda untuk mengetahui korelasi antar kelompok dan uji beda (t-test) untuk mengetahui perbedaan antar kelompok nilai tahanan jenis tersebut. Sehingga dapat dilakukan delineasi pada kelompok-kelompok nilai tahanan jenis yang sesuai dengan tujuan penelitian. Analisis statistik ini menggunakan bantuan perangkat lunak SPSS (Statistical Product and Service Solutions) ver. 20.

Langkah terakhir merupakan tahap visualisasi dan validasi menggunakan pendekatan analisis spasial dengan melakukan perbandingan antara model tahanan jenis yang dibuat dengan kondisi geologi permukaan dan hasil pemboran. Pembuatan model dilakukan dengan menggunakan perangkat lunak Rockworks ver. 15 serta ArcGIS ver. 10 .

\section{TATAAN GEOLOGI DAERAH PENELITIAN}

Rusmana, dkk. (1991) dalam Peta Geologi Lembar Serang dan Santosa (1991) dalam Peta Geologi Lembar Anyer menguraikan kondisi geologi regional di sekitar daerah penelitian. Berdasarkan peta-peta tersebut diketahui bahwa batuan tertua yang menyusun daerah penelitian adalah batuan lava andesitis-basaltis yang terkekarkan, breksi vulkanik, dan tuf. Batuanbatuan ini merupakan bagian dari endapan vulkanik tua Danau yang tersingkap di bagian baratdaya daerah penelitian. Pada bagian tengah daerah penelitian terdapat endapan vulkanik sebagai produk Gunung Kamuning, Gunung Marikangen, dan Gunung Payung - Gedor. Batuan-batuan ini disusun oleh batuan beku piroksen andesit - basalt, breksi tuf andesitis yang terkekarkan dan terlapukkan. Batuan andesit Pasir Terbang kemudian menerobos endapan vulkanik Payung - Gedor.

Seluruh batuan vulkanik tersebut ditutupi oleh Tuf Banten (tuf berbatuapung dan batupasir tufan) dan endapan vulkanik muda Danau (batuan lava andesitis-basaltis yang mengandung kekar, breksi vulkanik, dan tuf), yang mendominasi bagian utara daerah penelitian. Batuan termuda yang tersingkap adalah hasil letusan gunungapi Gunung Karang dan Gunung Parakasak. Produk vulkanik Gunung Karang disusun oleh breksi vulkanik, tuf, lahar yang tak teruraikan, dan lava (piroksen andesit basalt). Produk vulkanik Gunung Parakasak disusun oleh breksi vulkanik, lava, tuf, lahar, dan material vulkanik lainnya. Pada bagian timur, terdapat endapan Rawa Danau yang terdiri dari kerikil, pasir, lempung, dan lumpur, yang semuanya berasal dari batuan vulkanik.
Zaenudin (1985) menyatakan bahwa berdasarkan pendugaan geolistrik di daerah Cinangka, Padarincang, Ciomas dan Pabuaran, material permukaan tersusun oleh tanah lempung pasiran dan tanah pasir tufan dengan ketebalan diperkirakan antara 2 sampai dengan 3 meter. Pada bagian bawah diduga sebagai tuf pasiran dan pasir tufan dengan ketebalan 3 sampai dengan 40 meter, dan pada bagian bagian utara terdapat breksi. Endapan bagian bawahnya lagi berupa tuf pasiran, pasir, kerikil, kerakal, dan bongkah dengan ketebalan antara 6 hingga 108 meter, sedangkan endapan yang paling bawah diduga berupa batulempung pasiran.

Pemetaan geologi permukaan menghasilkan empat kelompok produk vulkanik yang ditemukan pada daerah penelitian, yaitu: produk vulkanik Gunung Karang, Gunung Parakasak, Gunung Kamuning, Gunungapi Tua (Gambar 2 \& 3). Secara rinci dijelaskan sebagai berikut:

a. Produk Vulkanik Gunung Karang

Terdiri dari aluvium, lava, breksi vulkanik, dan tuf. Lava andesitis Gunung Karang, yang memiliki ketebalan sekitar 5 meter, memperlihatkan struktur kekar berlembar, pada bagian bawahnya kontak dengan tuf lapili. Singkapan lava berwarna abu-abu tua, keras dan berstruktur vesikuler. Sayatan tipis memperlihatkan tekstur porfiritik, hipokristalin, hipidiomorf, dengan fenokris yang tersusun oleh plagioklas (18\%) berukuran $0,5-3 \mathrm{~mm}$ dan tersebar dalam matriks yang halus.

b. Produk Vulkanik Gunung Parakasak

Terdiri dari aluvium, lava, breksi vulkanik, dan tuf. Lava memiliki ketebalan sekitar $35 \mathrm{~cm}$, berupa batuan beku andesitis, berwarna kuning- coklat tua, bertekstur porfiritik. Sayatan tipis memperlihatkan tekstur hipokristalin, hipidiomorf, disusun oleh plagioklas (27\%) yang tidak berwarna hingga abu-abu dengan ukuran antara 0,5 - $3 \mathrm{~mm}$, beberapabagian telah teralterasi, dan piroksen yang berwarna hitam dengan ukuran $3 \mathrm{~mm}$ prismatik panjang. Arah jurus dan kemiringan pada kontak antara lava andesitis (baikbagianbawah maupun atas) dengan tuf adalah $\mathrm{N} 178^{\circ} \mathrm{E} / 22^{\circ}$.

c. Produk Vulkanik Gunung Kamuning

Terdiri dari lava dan tuf. Lava berupa batuan beku andesitis yang berwarna abu-abu tua, mempunyai tekstur porfiritik yang disusun oleh mineral plagioklas (30\%) dengan ukuran $0,1 \mathrm{~mm}$ hingga $4 \mathrm{~mm}$, keras, juga terlihat adanya struktur kekar berlembar (sheeting joint) dan vesikuler. Arah jurus dan kemiringan dari struktur kekar adalah $\mathrm{N} 12^{\circ} \mathrm{E} / 43^{\circ}$. 


\section{MAKALAH ILMIAH}

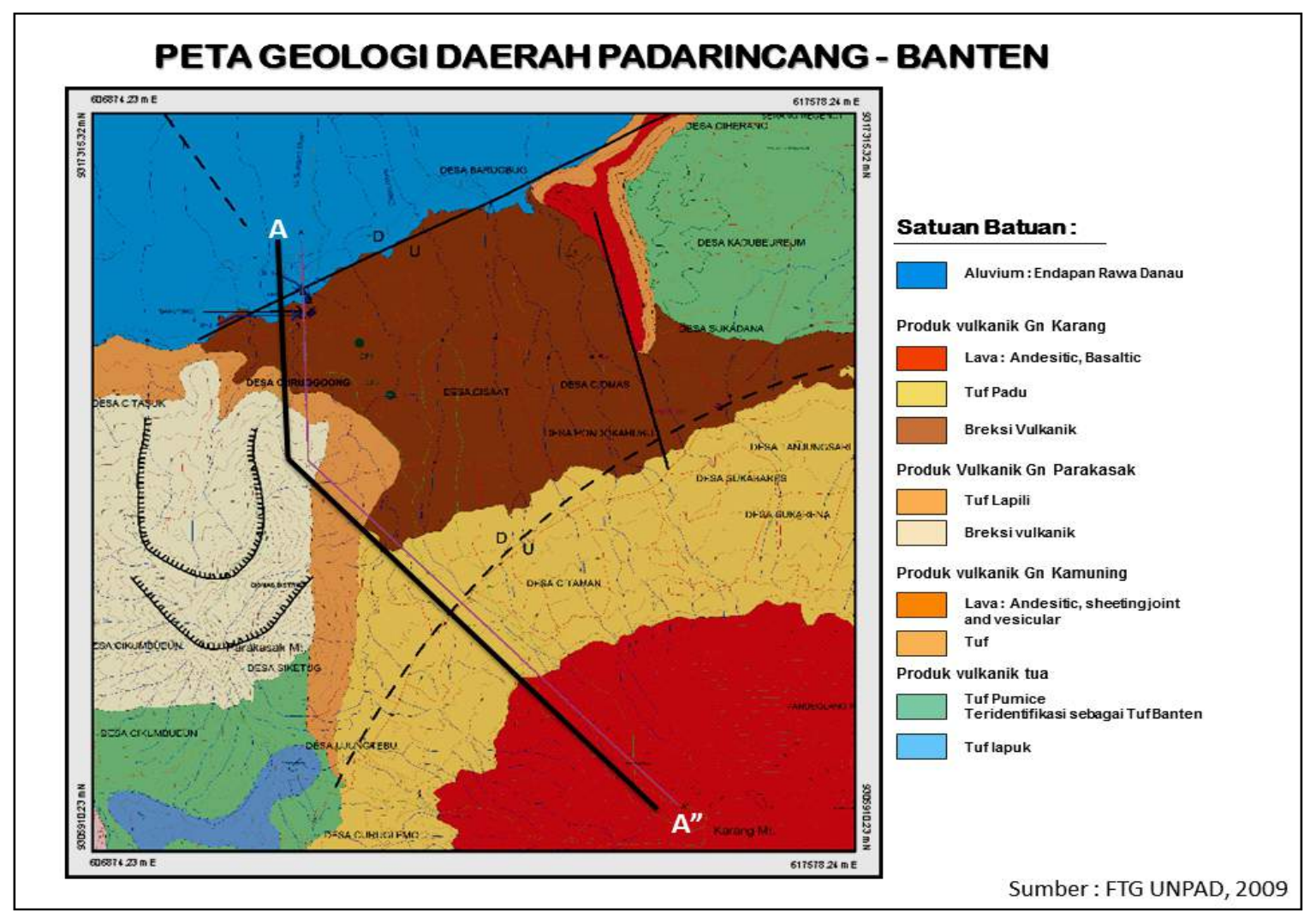

Gambar 2. Peta Geologi daerah penelitian (FTG UNPAD, 2009)

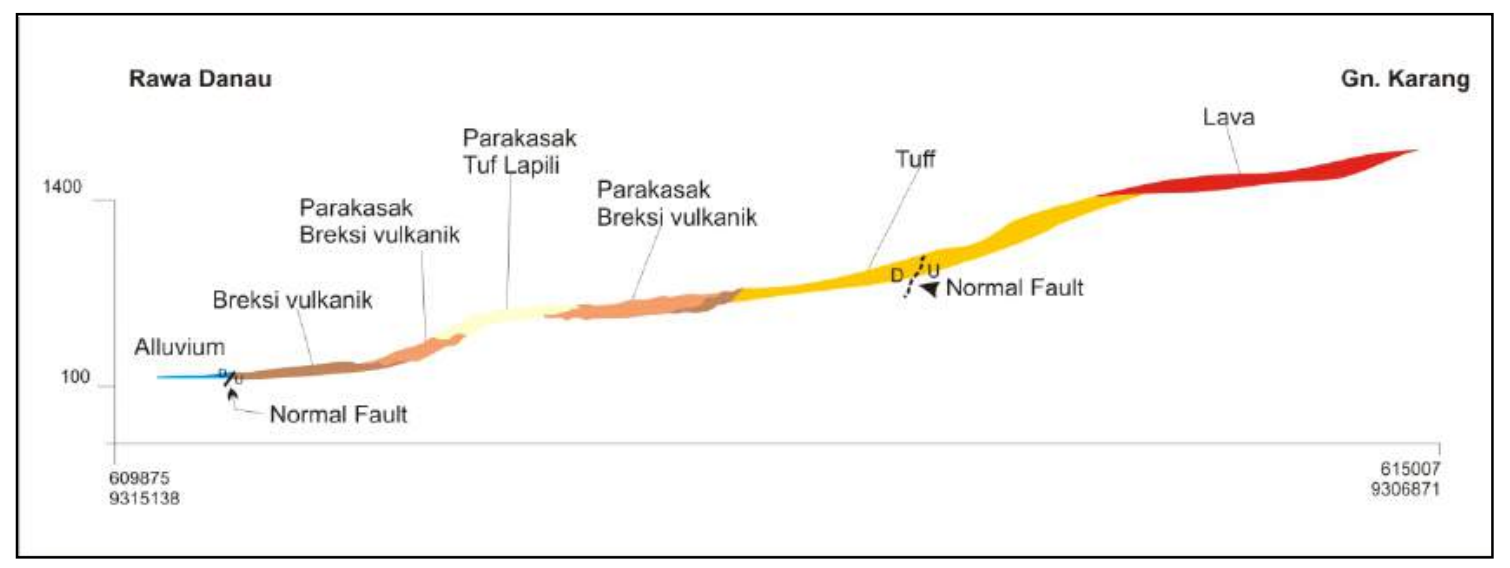

Gambar 3. Penampang utara-selatan (A - A") daerah penelitian (FTG UNPAD, 2009)

Singkapan tuf berwarna abu-abu muda, berukuran kasar hingga halus, masif, terpilah sedang, dan matrix-supported.

d. Produk Vulkanik Gunungapi Tua

Tersusun atas batuan tuf berbatuapung, breksi vulkanik, dan Tuf. Sifat dari produk hasil vulkanik gunungapi tua ini adalah memiliki fragmen batuan beku andesitis-basaltis, polimik. Tuf yang sudah sangat terlapukkan merupakan bagian dari endapan vulkanik Danau dan diperkirakan merupakan batuan tertua di daerah penelitian. Lateral continuity stratigrafi antara produk vulkanik GunungParakasak, Gunung Karang, Gunung Kamuning, dan Gunungapi Tua di daerah penelitian dibuat berdasarkan penelitian terdahulu, survey lapangan dan analisis laboratorium. Penampang geologi secara umum daerah penelitian memperlihatkan gambaran $\mathrm{k}$ a $\mathrm{p}$ a s i t a $\mathrm{s}$ kandungan air yang diperkirakan (Gambar 2). 


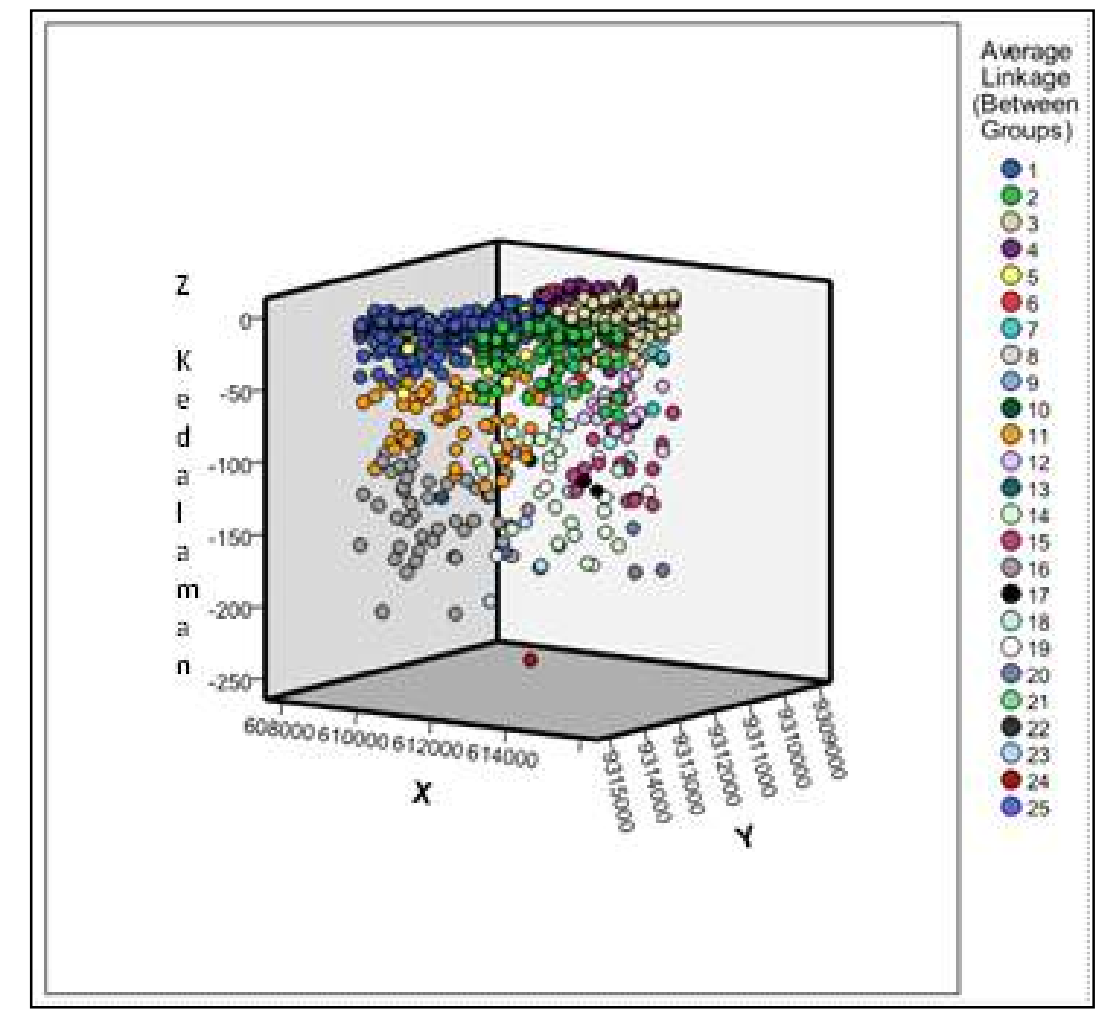

Gambar 4. Metode Hierarchy Cluster dalam penentuan kelompok populasi nilai tahanan Jenis

\section{HASIL DAN ANALISIS}

\section{Nilai Tahanan Jenis Pada Batuan Vulkanik}

Pengolahan statistik pada pendugaan tahanan jenis sebanyak 105 titik duga geolistrik dan 790 titik duga secara lateral dan vertikal. Sebagai upaya untuk mengetahui adanya keragaman populasi tahanan jenis pada daerah penelitian digunakan Metode Hierarchy Cluster sebanyak 25 kasus pengelompokkan data. Variabelvariabel yang digunakan untuk mengelompokkan nilai tahanan jenis tersebut terdiri atas 4 variabel yaitu variabel tahanan jenis, variabel lateral $x$ dan $y$, serta variabel vertikal $z$ berupa kedalaman pendugaan. Hasil pengelompokkan nilai tahanan jenis diperlihatkan pada Gambar 4.

Pengolahan data nilai tahanan jenis dengan metode ini menghasilkan 25 kelompok, sebanyak 5 kelompok data diabaikan karena hanya terdiri dari 1-2 anggota. 20 kelompok nilai tahanan jenis sisanya kemudian diuji menggunakan uji regresi sehingga menghasilkan 17 kelompok.

Uji regresi linier berganda dengan mengunakan perangkat lunak SPSS menghasilkan 2 populasi nilai tahanan yaitu populasi pertama terdiri atas 11 kelompok nilai tahanan jenis yang memiliki nilai regresi atau $\mathrm{R}$ lebih kecil dari 0,5 dinyatakan sebagai populasi dengan variabel $x, y, z$ kurang berpengaruh (lemah) terhadap nilai tahanan jenis.Populasi kedua terdiri atas 6 kelompok nilai tahanan jenis memiliki nilai koefisien regresi $R$ yang lebih besar dari 0,5 dinyatakan sebagai populasi dengan variabel $\mathrm{x}, \mathrm{y}, \mathrm{z}$ berpengaruh kuat pada nilai tahanan jenis. Berdasarkan nilai kuat pengaruh tersebut maka dipilih 6 populasi dimana variabel lateral dan variabel vertikal memiliki pengaruh yang kuat terhadap nilai tahanan jenis. (Tabel. 1)

Berdasarkan hasil validasi pemboran yang dilakukan pada beberapa titik bor dan titik duga geolistrik, ke-6 kelompok nilai tahanan jenis tersebut diperkirakan merupakan batuan vulkanik yang dijelaskan pada Tabel 2 .

Lapisan batuan yang berada di daerah penelitian terdiri atas : Lapisan batuan yang berada di bagian utara daerah penelitian adalah lapisan 1 berupa breksi padu (grain supported) dengan nilai tahanan jenis $600-900$ Ohm pada kedalaman 1-12 meter, lapisan 2 berupa tuf lapili dengan nilai tahanan jenis 6-160 Ohm pada kedalaman 39-140 meter, dan lapisan 3 berupa tuf kasar dengan tahanan jenis 9-94 Ohm pada kedalaman 65-112 meter. Lapisan 4 dengan tahanan jenis 390-500 Ohm hanya muncul di bagian tengah daerah penelitian pada 
Tabel 1.

Koefisien regresi pada populasi dengan kuat pengaruh antar variabel

\begin{tabular}{|c|r|r|r|r|r|r|r|r|r|r|}
\hline Populasi & R & R Square & $\begin{array}{c}\text { Adjusted } \\
\text { R Square }\end{array}$ & $\begin{array}{c}\text { Std. Error } \\
\text { of the } \\
\text { Estimate }\end{array}$ & $\begin{array}{c}\text { R Square } \\
\text { Change }\end{array}$ & F Change & df1 & df2 & N & $\begin{array}{c}\text { Sig. F } \\
\text { Change }\end{array}$ \\
\hline 19 & 0.5552 & 0.3083 & -0.3835 & 70.0580 & 0.3083 & 0.4456 & 3 & 3 & 7 & 0.7380 \\
\hline 11 & 0.5568 & 0.3100 & 0.2607 & 34.8921 & 0.3100 & 6.2908 & 3 & 42 & 46 & 0.0013 \\
\hline 14 & 0.7173 & 0.5145 & 0.4235 & 20.0875 & 0.5145 & 5.6525 & 3 & 16 & 20 & 0.0078 \\
\hline 10 & 0.7687 & 0.5910 & -0.6361 & 141.7693 & 0.5910 & 0.4816 & 3 & 1 & 5 & 0.7548 \\
\hline 18 & 0.9660 & 0.9331 & 0.7325 & 18.0564 & 0.9331 & 4.6516 & 3 & 1 & 5 & 0.3255 \\
\hline 17 & 0.9989 & 0.9978 & 0.9913 & 5.1067 & 0.9978 & 152.6698 & 3 & 1 & 5 & 0.0594 \\
\hline
\end{tabular}

\begin{tabular}{|c|c|c|c|}
\hline B & $X$ & $Y$ & $Z$ \\
\hline 0.726 & 0.394 & 0.740 & 0.689 \\
\hline 0.029 & 0.010 & 0.018 & 0.211 \\
\hline 0.004 & 0.127 & 0.004 & 0.070 \\
\hline 0.717 & 0.707 & 0.771 & 0.760 \\
\hline 0.199 & 0.481 & 0.194 & 0.232 \\
\hline 0.043 & 0.177 & 0.041 & 0.041 \\
\hline
\end{tabular}

Tabel 2.

Hasil validasi nilai tahanan jenis dengan pemboran.

\begin{tabular}{|c|r|r|r|r|r|c|}
\hline \multirow{2}{*}{ Lapisan } & \multirow{2}{*}{ Kelompok } & \multicolumn{2}{|c|}{ Nilai Tahanan Jenis } & \multicolumn{2}{c|}{ Kedalaman } & \multirow{2}{*}{ Perkiraan Litologi } \\
\cline { 3 - 6 } & & Minimum & Maximum & Minimum & Maximum & \\
\hline 1 & 10 & 598.56 & 887.7 & -11.35 & -1.41 & Breksi Padu \\
\hline 2 & 11 & 6.86 & 162.26 & -111.94 & -39.14 & Tuf Lapili \\
\hline 3 & 14 & 9.02 & 94.07 & -159.53 & -65.95 & Tuf Kasar \\
\hline 4 & 17 & 394.2 & 532.17 & -120.27 & -70.55 & Breksigrain supported \\
\hline 5 & 18 & 46.07 & 116.76 & -142.85 & -93.26 & Tuf Lapili \\
\hline 6 & 19 & 232.54 & 400.93 & -181.55 & -116.95 & Breksimatrix supported \\
\hline
\end{tabular}

Tabel 3.

Kelompok nilai tahanan jenis yang memiliki nilai koefisien regresi tinggi.

\begin{tabular}{|c|r|r|r|r|r|r|r|r|r|r|}
\hline Kelompok & $R$ & $R$ Square & $\begin{array}{c}\text { Adjusted } \\
\text { R Square }\end{array}$ & $\begin{array}{c}\text { Std. Error } \\
\text { of the } \\
\text { Estimate }\end{array}$ & $\begin{array}{c}\text { R Square } \\
\text { Change }\end{array}$ & F Change & df1 & df2 & $N$ & $\begin{array}{c}\text { Sig. F } \\
\text { Change }\end{array}$ \\
\hline 18 & 0.9660 & 0.9331 & 0.7325 & 18.0564 & 0.9331 & 4.6516 & 3 & 1 & 5 & 0.3255 \\
\hline 17 & 0.9989 & 0.9978 & 0.9913 & 5.1067 & 0.9978 & 152.6698 & 3 & 1 & 5 & 0.0594 \\
\hline
\end{tabular}

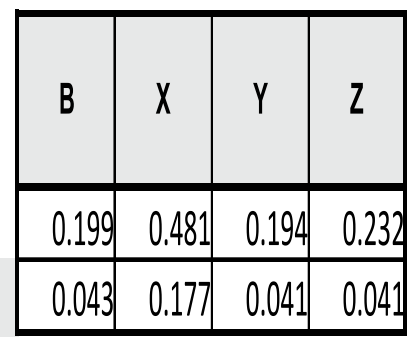

kedalaman 70-100 meter. Sedangkan lapisan batuan pada bagian selatan daerah penelitian terdiri atas lapisan 5 dengan nilai tahanan jenis 40-100 Ohm pada kedalaman 90-140 meter dan lapisan 6 dengan nilai tahanan jenis 200-400 Ohm pada kedalaman 100-200 meter.

\section{Pendugaan Sesar Pada Batuan Vulkanik}

Pendugaan sesar dilakukan berdasarkan adanya kecenderungan nilai koefisien regresi atau $R$ yang sangat tinggi, hal ini menandakan bahwa pada kelompok tersebut memiliki ciri yang unik dan tidak dipengaruhi oleh faktor lain, akan tetapi tidak terjadi multicolinearity. Kelompok yang termasuk pada kelompok ini adalah lapisan
4 (kelompok 17) dan lapisan 5 (kelompok 18) seperti terlihat pada Tabel 3.

Pada kedua kelompok ini terdapat kelurusan dimana pada lapisan 5 (kelompok 18) terdapat 2 kelurusan sejajar berarah barat laut tenggara. Sedangkan pada lapisan 4 (kelompok 17) terlihat jelas bahwa penyebarannya memiliki kelurusan yang berarah relatif barat timur. Kelurusan ini merupakan sekumpulan nilai tahanan jenis yang terkelompokkan dan memiliki rentang nilai yang sangat kecil akan tetapi memiliki beda yang sangat kontras dengan nilai-nilai di sekitarnya. Selain itu pula terdapat kemiripan nilai signifikansi yang hampir mendekati nilai 0,05 pada lapisan 4 dan lapisan 5 yaitu 0,065 . Perkiraan pada kemiripan karakter lapisan 


\section{MAKALAH ILMIAH}

Tabel 4.

Uji beda yang menunjukkan nilai signifikansi perbedaan antar lapisan

\begin{tabular}{|c|r|r|r|r|r|r|}
\hline Korelasi 2-tailed & Lapisan-1 & Lapisan-2 & Lapisan-3 & Lapisan-4 & Lapisan-5 & Lapisan-6 \\
\hline Lapisan-4 Pearson Correlation & 0.719 & -0.004 & -0.505 & 1 & -0.855 & 0.424 \\
Sig. (2-tailed) & 0.171 & 0.995 & 0.386 & & 0.65 & 0.424 \\
$\mathrm{~N}$ & 5 & 5 & 5 & 5 & 5 & 5 \\
\hline
\end{tabular}

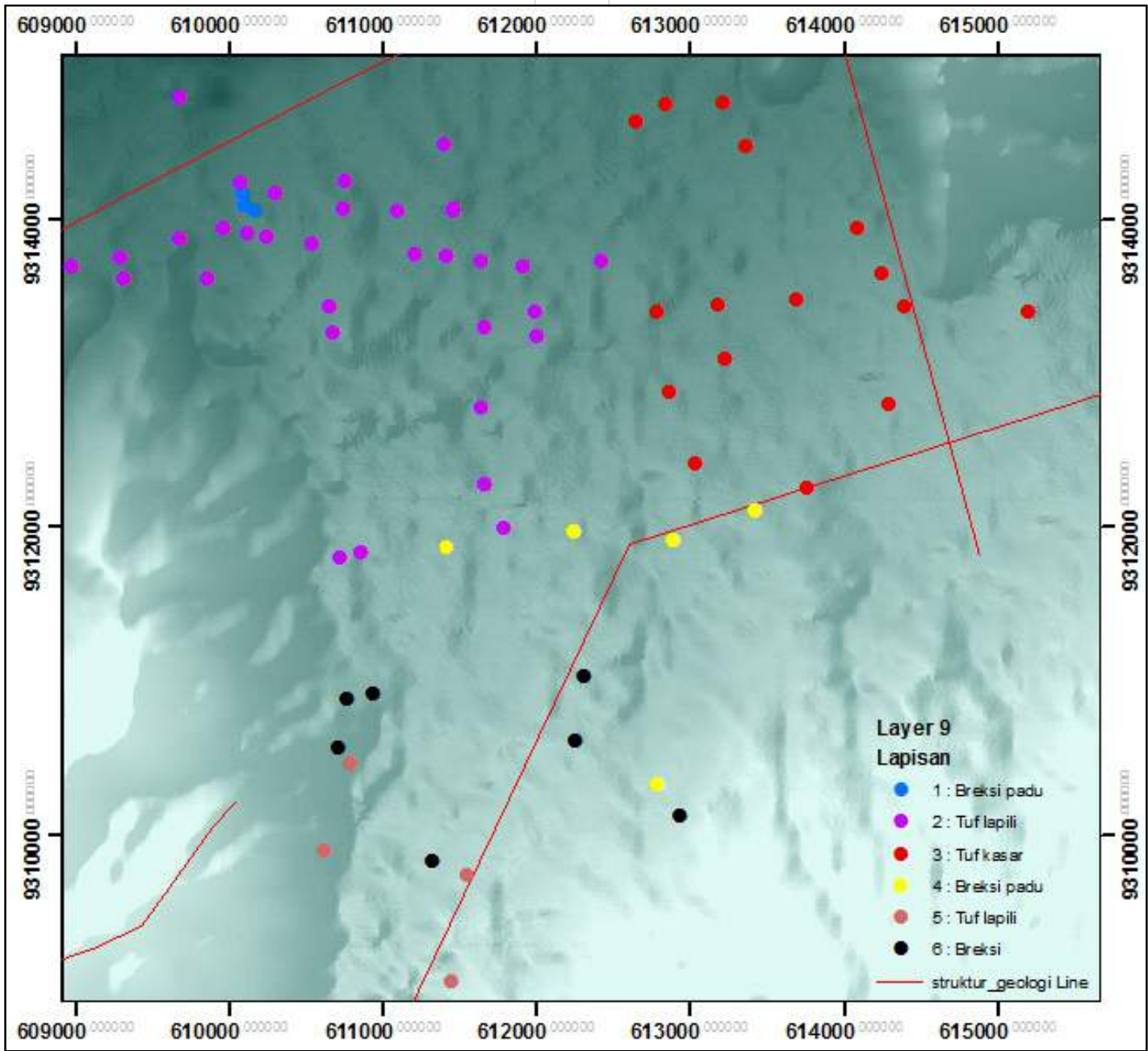

Gambar 5. Kelurusan pada lapisan 4 dan 5 yang ditumpangtindihkan dengan hasil interpretasi sesar pada pemetaan geologi

tersebut adalah sebagai akibat adanya dislokasi atau pergeseran yang ditimbulkan oleh sesar pada lokasi ini (Tabel 4).

Kelurusan pada lapisan 4 dan lapisan 5 ternyata memiliki kesesuaian dengan struktur geologi saat ditumpangtindihkan pada peta geologi. Peta ini merupakan hasil interpretasi pengamatan singkapan dan indikasi yang ada pada pemetaan geologi. Kesesuaian pada kelompok 17 tersebut menambah keyakinan bahwa interpretasi nilai tahanan jenis kelompok 17 merupakan breksi sesar (Gambar 5).

\section{DISKUSI}

Dari nilai prediksi model regresi tahanan jenis maka didapatkan gambaran geologi bawah permukaan daerah penelitian. Gambaran ini 


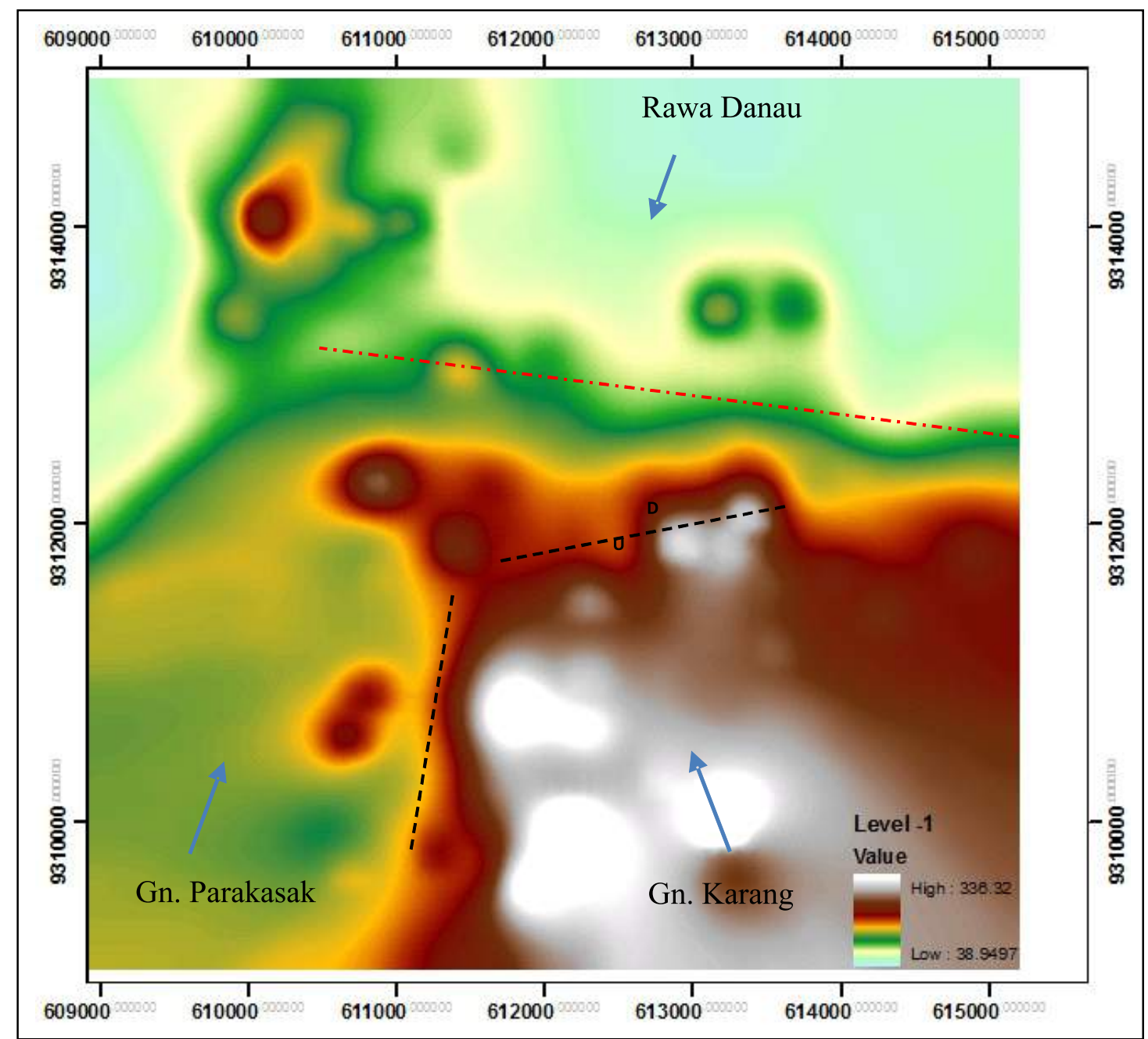

Gambar 6. Model tahanan jenis menunjukkan adanya 3 sumber pengendapan yaitu dari Gunung Parakasak, Gunung Karang dan endapan Rawa Danau, serta zona sesar yang berkembang.

merupakan hasil interpolasi dari nilai-nilai regresi tahanan jenis dengan menggunakan metode interpolasi inverse distance weighting.

Endapan yang bersumber dari Gunung Parakasak merupakan endapan yang pertama kali di endapkan pada daerah ini, tersusun dari batuan yang memiliki tahanan jenis antara 50 $400 \mathrm{Ohm}$. Diduga endapan yang berasal dari Gunung Parakasak ini merupakan tuf, tuf lapilli dan breksi matrix-supported. Endapan yang bersumber dari Gunung Karang diendapkan di atas endapan Gunung Parakasak yang diduga tersusun atas breksi matrix-supported dan breksi grain-supported, pada endapan Gunung Karang ini diduga banyak material yang memiliki nilai tahanan jenis di atas $400 \mathrm{Ohm}$ atau material keras dan tidak mengandung airtanah.

Endapan yang bersumber dari Rawa Danau merupakan endapan sedimen, dimana endapan danau tersebut merupakan produk endapan gunungapi tua yang berasal dari proses vulkanisma Gunung Kamuning yang tersedimentasi pada lingkungan danau. Material yang halus terlihat dari nilai tahanan jenis yang berkisar dari 10-100 Ohm, dengan nilai tahanan jenis rata-rata $50 \mathrm{Ohm}$. Endapan ini terletak di bagian utara daerah penelitian. Pada pola isoresistivity memperlihatkan suatu kelurusan yang menjadi batas antara endapan Rawa Danau dan Gunung Karang. Kelurusan tersebut memiliki arah hampir barat-timur atau sekitar $\mathrm{N} 100^{\circ} \mathrm{E}$ berada pada bagian tengah daerah penelitian dan diyakini sebagai sesar yang berkembang. Sesar terjadi sebelum adanya pengendapan material dari Rawa Danau sehingga sesar tersebut menjadi batas endapan Rawa Danau (Gambar 6).

Model regresi tahanan jenis memperlihatkan suatu pola tahanan jenis yang memiliki kelurusan pada lokasi-lokasi tertentu. Pada model ini terdapat dua kelurusan dengan nilai tahanan jenis di atas 300 Ohm yang diduga merupakan breksi sesar. Kelurusan ini diinterpretasikan sebagai sesar normal dengan bagian yang turun adalah blok Gunung Karang (pada bagian tenggara daerah penelitian). Selain itu, kontak 
litologi membentuk suatu kelurusan pada pola kontur isoresistivity. Kemunculan indikasi struktur geologi berupa kelurusan berada pada kedalaman 70 meter (relatif di bagian selatan) dan 100 meter (berada relatif lebih utara). Dengan demikian arah pergerakan sesar ini diperkirakan sekitar $\mathrm{N} 255^{\circ} \mathrm{E}$.

Sedangkan pada bagian selatan daerah penelitian muncul kelurusan dengan arah $\mathrm{N} 25^{\circ} \mathrm{E}$, pada kedalaman yang sama. Kemunculannya pada lokasi hampir sama yaitu pada kedalaman 100 meter dan 120 meter. Kelurusan ini pun diinterpretasikan sebagai sesar normal dimana blok Gunung Karang (bagian timur) relatif turun. Sesar ini terjadi diduga karena adanya proses vulkanik Gunung Karang dan material yang bersifat padat seperti breksi grain-supported dengan komponen-komponen yang besar serta lava terendapkan pada blok ini yang kemudian mengalami pembebanan dan penurunan (Gambar 5).

\section{KESIMPULAN}

Penelitian mengenai analisis nilai tahanan jenis menggunakan pendekatan statistik dengan Metode Hierarchy Cluster dan pengujian keeratan hubungan antara variabel nilai tahanan jenis, variabel lateral dan variabel vertikal. Hasil penelitian dapat disimpulkan sebagai berikut: a. Kesamaan nilai tahanan jenis dengan arah relatif barat-timur yang menunjukkan kesamaan litologi dengan sumber pengendapan yang berbeda, yaitu endapan Gunung Parakasak dari arah barat daya, Gunung Karang dari arah tenggara, dan Gunung Kamuning dari arah utara.

b. Perbedaan nilai yang kontras dengan arah relatif utara-selatan menunjukkan adanya dua jenis sesar yang ditunjukkan dengan adanya batas endapan material Rawa Danau dan sesar yang berkembang sebagai akibat pembebanan material Gunung Karang.

Dengan demikian adanya pembagian kelompok nilai tahanan jenis berdasarkan pada karakteristiknya lebih mampu menjelaskan struktur geologi yang berkembang pada daerah vulkanik.

\section{UCAPAN TERIMA KASIH}

Penulis mengucapkan terima kasih kepada Dekan Fakultas Teknik Geologi Universitas Padjadjaran yang telah memberikan dukungannya, kepada PT. Aqua Tirtainvestama yang telah memberikan ijin untuk penggunaan datanya, kepada Dr. Ir. H. Dicky Muslim, M.Sc; Ir. Rahardjo Hutamadi; Ir. Bambang Pardiarto, serta seluruh Tim Editor untuk saran dan masukannya dalam perbaikan makalah ini.

\section{DAFTAR PUSTAKA}

Cas R.A.F., \& Wright J.V., 1987, Volcanic Sucessions, Allen \& Unwin Ltd., London.

FTG UNPAD, 2009, Penelitian Hidrogeologi Daerah Ciomas dan Sekitarnya untuk PT. Tirta Investama. Fakultas Teknik Geologi, Universitas Padjadaran, tidak dipublikasikan.

Hald A., 1952, Statistical Theory with Engineering Applications, John Wiley \& Sons, New York.

Hirnawan F., 2007, Riset Bergulirlah Proses Ilmiah. Unpad Press. Bandung.

Nemeth, K and Martin, U., 2007, Practical Volcanology. Lecture Notes for Understanding Volcanic Rock. Geological Institute of Hungary, vol 207.

Oosterbaan R.J., Boonstra J., Rao K.V.G.K., 1996, The Energy Balance of Groundwater Flow in Singh \& Kumar (eds.) Subsurface Water Hydrology, Kluwer Academic Publ., Dordrecht, The Netherlands.

Ruswana, Suwitodirdjo, Suharsono, 1991, Peta Geologi Regional Lembar Serang, Pusat Penelitian dan Pengembangan Geologi, Bandung.

Santosa, 1991, Peta Geologi Regional Lembar Anyer, Pusat Penelitian dan Pengembangan Geologi, Bandung.

Supranto, J., 2004, Analisis Multivariat: Arti dan Interpretasi, Penerbit Rineka Cipta, Bandung.

Zaenudin, 1985, Laporan Hasil Survey Geolistrik. Penelitian Hidrogeologi Kaki Gunung Ciomas, Padarincang, Pabuaran. Bandug, tidak dipublikasikan. 